Portland State University

PDXScholar

$11-9-1994$

\title{
Strategies in Theodore Dreiser's Trilogy of Desire to Resolve the Division Between the Material and the Spiritual
}

Claas Riese

Portland State University

Follow this and additional works at: https://pdxscholar.library.pdx.edu/open_access_etds

Part of the English Language and Literature Commons Let us know how access to this document benefits you.

Recommended Citation

Riese, Claas, "Strategies in Theodore Dreiser's Trilogy of Desire to Resolve the Division Between the Material and the Spiritual" (1994). Dissertations and Theses. Paper 4792.

https://doi.org/10.15760/etd.6676

This Thesis is brought to you for free and open access. It has been accepted for inclusion in Dissertations and Theses by an authorized administrator of PDXScholar. Please contact us if we can make this document more accessible: pdxscholar@pdx.edu. 


\section{THESIS APPROVAL}

The abstract and thesis of Claas Riese for the Master of Arts in English were presented Nov. 9, 1994, and accepted by the thesis committee and the department.

COMMITTEE APPROVALS:

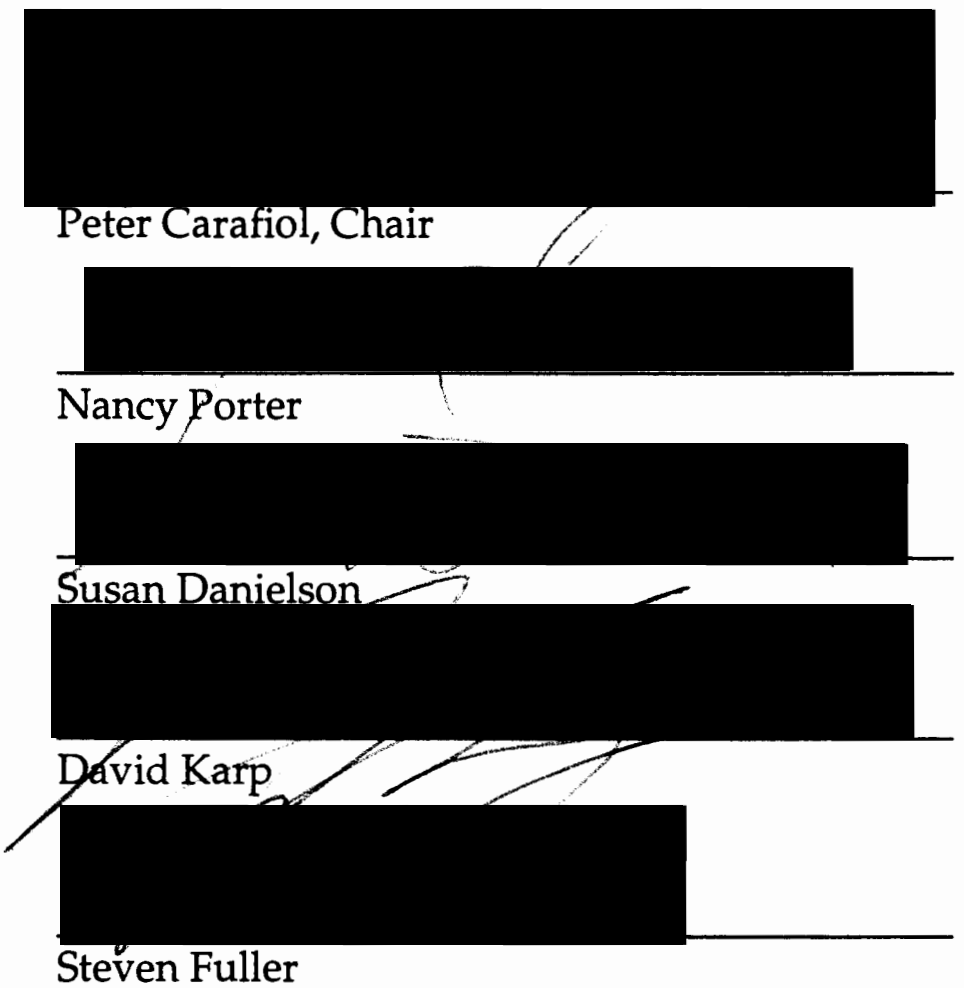

Representative of the Office of Graduate Studies

DEPARTMENT APPROVAL:

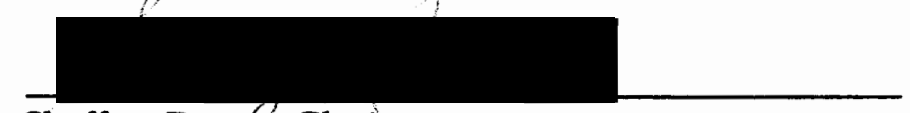

Shelley Reege, Chair

Department of English

ACCEPTED FOR PORTLAND STATE UNIVERSITY BY THE LIBRARY

by on 27 Weemhe 1984 


\begin{abstract}
An abstract of the thesis of Claas Riese for the Master of Arts in English presented Nov. 9, 1994.

Title: Strategies in Theodore Dreiser's "Trilogy of Desire" to resolve the division between the material and the spiritual.
\end{abstract}

A study of strategies and attempts in Theodore Dreiser's novels The Financier, The Titan and The Stoic to resolve the conflict between the material and the spiritual. The purpose of this thesis is to demonstrate that conflicts in Dreiser criticism reflect unresolved conflicts between these issues in his "Trilogy". Having outlined and shown the division in the literary criticism of the "Trilogy", in the first chapter of this thesis, I will discuss the three main themes, finance, art and women, which can be seen as strategies to bridge the division between the material and the spiritual. I will attempt to transcend the traditional categorization of Dreiser criticism to come to a more complex understanding of the core issues of his writing. 
Strategies in Theodore Dreiser's "Trilogy of Desire" to resolve the division between the material and the spiritual

by

Claas Riese

A thesis submitted in partial fulfillment of the requirements for the degree of

\section{MASTER OF ARTS}

in

ENGLISH

Portland State University

1994 


\section{TABLE OF CONTENTS}

\section{PAGE}

ACKNOWLEDGMENTS $\ldots \ldots \ldots \ldots \ldots \ldots \ldots \ldots \ldots \ldots \ldots \ldots \ldots \ldots$.ii

\section{CHAPTER}

I Introduction $\ldots \ldots \ldots \ldots \ldots \ldots \ldots \ldots \ldots \ldots \ldots \ldots \ldots$

II $\quad$ Finance $\ldots \ldots \ldots \ldots \ldots \ldots \ldots \ldots \ldots \ldots \ldots \ldots \ldots, 18$

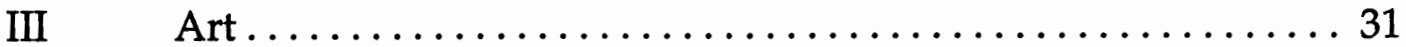

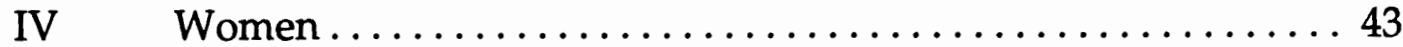

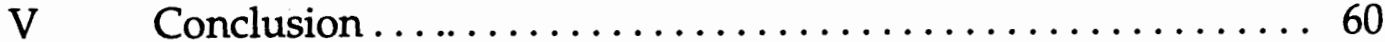

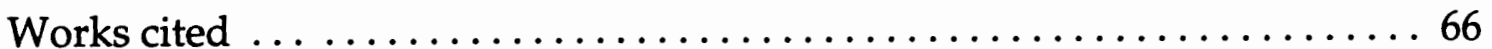




\section{Acknowledgments}

The thesis represented here is not just the result of my effort and work. I want to acknowledge my gratitude to Prof. Peter Carafiol for guiding me through this project with his insight, encouragement and a sense of humor. I especially appreciated his patient reading of this thesis and his experienced and humane coping with all the problems and concerns for which I sought his counsel. I also want to thank Nancy Porter for giving me her warm support in times of confusion and Sue Peltier, my friend, whom I could always count on for constructive advice. 
For my parents

and their unceasing love 


\section{Chapter One}

\section{Introduction}

The criticism of Theodore Dreiser and his work can be divided into three major, though sometimes overlapping, phases. In my attempt to explain these three phases I have omitted criticism from the early 1900's that focuses mainly on the social and ethical acceptability of his fiction. The subject matter of this work does not contribute to a critical discussion of my thesis. The phases that are of importance to this thesis can be divided as follows:

- Critical work that clearly classifies Dreiser's work as a reflection of his naturalistic ideas.

- The more recent trend of criticism that focuses on the spirituality and mystical elements of his work.

- Scholars who point at Dreiser's conflicting ideas concerning evolutionary thought, naturalism and tendencies toward mysticism and spirituality. These three phases do not always fit into a certain historical context and I have therefore distanced myself in classifying them from an historical perspective, though certain phases seem to reach a climax due to historical events or predominant social issues. Criticism on Dreiser's "barbaric" naturalism, for instance, reached its highest level during World War I. One particular essay, originally entitled "The Barbaric Naturalism of Theodore Dreiser", which was later published under a more moderate title as "The Naturalism of Mr. Dreiser" by Stuart P. Sherman exemplifies this phase. In contrast some recent scholars refute 
the idea of Dreiser's mechanistic, naturalistic view of the world, with which he has often been identified. Others point to the conflicting ideas that influenced Dreiser's writing and explain his reconciliation of these conflicts as a return to romanticism or transcendentalism. Whether in early or recent criticism, what many of these scholars have in common is an urgency to place Theodore Dreiser in a category, and if a critic senses a conflict in Dreiser's writing, again he/she tries to confine it to a single literary or philosophical category. The division emerging out of the conflicting interpretations of critics who assume that Dreiser's work can be read merely as a naturalist, a spiritualist or a romanticist or a blending of all of these, indicates a major division and conflict in Dreiser's "Trilogy". Any category in which we try to frame Dreiser, limits an attempt to understand this division and therefore creates a possibility of overlooking certain aspects and ideas that might not fit in the neatly framed picture.

In a textual discussion of Dreiser's work the following biographical material might be dismissed as irrelevant, however it helps illuminate the conflicts and issues Dreiser struggled with during his career as a writer. Richard Lingeman's essay, "Mencken, Dreiser and God," demonstrates the argument and development of the quarrel about religion, God etc. between Dreiser and his critic and probable best friend, H.L. Mencken. The argument between the two men lasted for many years until the end of Dreiser's life, and was triggered when Mencken submitted an essay on religion, in which he attacked the concept of prayer. Dreiser, however, was of the opinion that scientific knowledge was a form of prayer. He contended that scientists were endeavoring to learn the ultimate laws of the universe and the nature of God. Mencken on the other hand believed that science and religion were antithetical. His view becomes clearer when looking at the way he critiqued Iennie Gerhart: Mencken wrote that the 
novel embodied "'the doctrine that life is meaningless, a tragedy without a moral, a joke without a point'" (3). When Dreiser sent Mencken a copy of his latest manuscript of The Genius, he was appalled. He realized that his friend had changed from "a bleak agnostic who found life meaningless and was now wallowing in metaphysical bilge"(4). Among other things he rejected the hero's conversion to Christian Science in The Genius. Mencken's criticism was so influential on Dreiser that he later altered the ending so that the hero does not convert to Christian Science, though he consulted a healer instead. Dreiser told a friend once that Mencken lacked "' a sense of beauty', that he was too materialistic, interested only in the "'visible face of life,"' (7) unlike Dreiser, who was seeking to understand the "invisible mechanism with which science is always concerned ... (the) reasons, if any for our being here'". Dreiser took such criticism into consideration. At times he was deeply hurt, but overall he followed his intuition, passions and emotions for his instruction. The main subject of argument was Mencken's inability to understand Dreiser's deep need to find an answer to the question, "Why are we here?" or his passion for social justice, sparked by his boyhood poverty (9). The conflict between these two men illustrates in particular the issue of materialism versus spirituality. Mencken as one of Dreiser's most passionate critics fell into the same trap as did many critics that followed. As soon as Mencken believed he could categorize Dreiser as the bleak agnostic, which coincided with his personal conviction, the conflict between the two men was hidden. Later when Dreiser's ideas became more complex, he broke the narrow frame that Mencken wanted him to fit in, creating a lifelong conflict between them--and as we shall see, in Dreiser's own work. The dictatorial Mencken insisted on the division between the spiritual and the material, which was an idea Dreiser couldn't accept as a satisfactory solution for himself, yet each 
school of criticism has insisted on taking sides, like Mencken, and on seeing Dreiser as one thing or another--spiritualist or materialist, whether conflicted or not.

This introduction will outline and recognize the tendencies of different literary camps in an attempt to identify their assessments, both strengths and weaknesses. The study of Dreiser criticism has helped me see the tension and conflicting ideas of the criticism which mirror an important conflict in Dreiser's work yet are unable to address it. My approach consists of transcending the existing criticism, to analyze without the restrictions of categorization in order to identify the core issues of Dreiser's writing. I will begin with the scholarship that identifies Dreiser as the stereotypical literary naturalist, moving on to the development against the above mentioned and finally toward the more complex approach of critics who point at the conflicting ideas in Dreiser. The last school of critics is closest to my approach yet still problematic in its emphasis on embodying single categories rather than discussing how the split has been dramatized in the books. The selection of these essays and books is selective in order to demonstrate the various phases and does not claim to be complete.

Eliseo Vivas tries to understand Dreiser from the widely accepted viewpoint of the author as the representative of American Literary Naturalism in his essay, "Dreiser, an Inconsistent Mechanist". The scholar scrutinizes Dreiser's naturalistic philosophy. It is important to see that Vivas never conceives Dreiser to be anything other than a naturalist, though he points at Dreiser's wide range of vision and his deep sense of the relation of man to the cosmos. From this point of view the scholar notices an inconsistency between the belief that life has no transcendent meaning, acknowledged by naturalists, and Dreiser's work. Vivas argues that Dreiser's intellectual vision of the world is not congruous with his 
vision as a novelist. The philosophy that Dreiser described in essays or editorial comments, appears "not always true to the record" (34). The critic sees the true magnificence of the poet not in his mechanistic world-view but in his dramatic vision of the world. The scholar dismisses the previous (before 1938) violent reaction by conservative critics since they missed seeing that Dreiser's "dramatic picture of society and of morality do not corroborate the theories which he has put forth" (35). Dreiser's characters can often be perceived as a-social forces, destroying the social equilibrium and they do not seem to correlate with the hard picture of atomic entities characteristic of Naturalism. Vivas concludes with the assumption that Dreiser "is a bigger and more faithful artist than his philosophy permits him to be" (37). Within his novels, Vivas acknowledges that Dreiser's characters always discover life to have a significance which overpowers them, one beyond its simple material, environmental force. The critic describes Dreiser's conflict in his childhood training, which he never outgrew. Intellectually Dreiser seems to know that the universe is a purposeless affair, but emotionally he is seeking an answer, seeking for transcendent support. Vivas, obviously a follower of Spinoza who states that the universe cannot but be, "since purpose and therefore value, are relative human affairs" (37), suggests Dreiser had never learned this lesson. No doubt he is right, but that is precisely the point. We must see Dreiser as he is, not suggest what he ought to be.

Stuart P. Sherman represents the peak of the discussion of Dreiser's work as a pure Naturalist. His essay entitled "The Naturalism of Mr. Dreiser" was published in 1915. Sherman focuses on the five novels Dreiser had published until 1915: Sister Carrie 1901, Jennie Gerhart, 1911, The Financier 1912, The Titan 1914 and The Genius 1915. The scholar finds that these five novels constitute a "homogeneous mass of fiction (5)" , which are illustrations of a "crude and 
naively simple naturalistic philosophy" (7). Sherman's argument rests on the assumption that each book is built on some "brutal generalizations" (7): Society is interpreted as a jungle in which the struggle for existence continues, legal, moral or social conventions have practically no influence on the cruel struggle, man is comparable to an animal, driven by desires, temperament and limited only by his own power. The characters, argues Sherman, are stereotypical and function according to jungle laws. Repeatedly the critic tries to explain Dreiser's so called "stubborn insistence upon the jungle motive" (11) with various textual examples from the previously mentioned five novels. The same word that Stuart P. Sherman uses to critique Dreiser's work can be applied to the critic himself. He holds against Dreiser that in all his novels, the quintessential point is the jungle-motive. The only achievement Sherman is able to find in the protagonist Frank A. Cowperwood is a rapacious appetite for money and women. The Titan repeats the same statement in sixty-two chapters. Sherman goes to great length repeating the same point, verifying it with numerous textual passages. This criticism might seem oversimplified and moralistic, but nonetheless in 1915 Sherman had just five novels to critique. Almost eighty years later our viewpoint has changed; Dreiser died in 1947 and we are able to analyze his entire work. Nonetheless it can't be dismissed that Dreiser has often been associated with the naturalists and been read and interpreted in Sherman's mechanistic way.

Even more contemporary critics such as Donald Pizer, whose essay on “Dreiser's American Literary Naturalism" was published in 1977, follow this line of criticism. Pizer argues that Dreiser is the author whose "work and career most fulfill the received notion of American Naturalism" (146). Some of Pizer's assumptions are that Dreiser accepted the scientific mechanistic theory of natural law as a, ". . substitute for traditional views of individual insight and moral re- 
sponsibility, yet [he affirmed] many of these traditional views; ..." (147). With the underlying assumption of Dreiser's "acceptance" of a scientific mechanistic theory (which has often been questioned) Pizer intends to prove and clarify his point by looking at two of Dreiser's eight novels: Jennie Gerhart and An American Tragedy. It is risky to assume from a selection of these two novels and some facts of Dreiser's life (his position of an outsider which was supposed to lead to a contemptuous view of the main stream of middle-class American life) that Dreiser fulfills the conventional definitions of the American naturalist. Donald Pizer notes that Dreiser held two different views at different stages of his career. On one side the scholar describes these ideas as a mechanistic world of beauty (such as in The Bulwark) and on the other side a cruelly indifferent

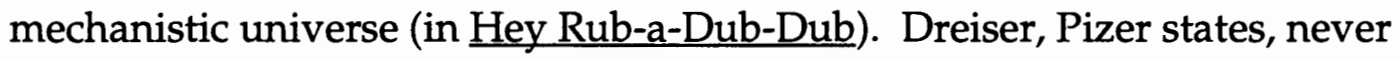
acknowledged these views as discrepant; "there was only the reality of distinctive temperaments which might find truth in each position, as in his [Dreiser's] own case, of a temperament which might find an element of truth in both" (151). Concluding, the scholar finds Dreiser's naturalistic "philosophy" to be secondary within the fictional dynamics of each novel to the role of the "concept as a metaphor of life against which various temperaments can define themselves" (151). However Pizer clearly sees the philosophy and the fiction as inseparable. It also seems to him a logical assumption that Dreiser absorbed and used naturalistic ideas because he was a late nineteenth century novelist, which is another bold assumption because it doesn't point to specific inferences. Finally Pizer believes that Dreiser's strength as a novelist can be found in his commitment to the "distinctive form of his naturalistic beliefs and in his ability to transform these beliefs into acceptable character and event" (154). In other words Pizer cannot but explain Dreiser as the naturalistic writer who we can only profit 
from by our willingness to accept his naturalism. Considering that this essay was published as late as 1977 shows that the various trends of Dreiser criticism cannot be ordered historically, but rather by the various categories by which critics have tried to grapple with Theodore Dreiser. More complicated responses to Dreiser's work are developed by a number of scholars, such as Alan Wycherly, Myoko Takeda and Barbara Hochmann.

A plausible explanation of trends in more recent criticism is voiced by Alan Wycherly, who observes that early scholars most frequently characterized Dreiser as a pessimistic naturalist based on their reading of his first six novels, the most famous and readable of his work. Much of Dreiser's writing appeared posthumously, including his final two novels. The metaphysical and even spiritual subject matter of these works has caused more recent scholars to reinterpret Dreiser's earlier novels as well as to reevaluate his place in American literature as a writer much too complex to be categorized simply as a naturalist. Dreiser's complexity is reflected in the diverse and sometimes controversial critical reception of today. Many recent scholars attempt to unify Dreiser's fiction through his long-standing relationship to spirituality and transcendence. Miyoko Takeda sees Dreiser's use of Hinduism in The Stoic as being consistent within the canon, "'it shows Dreiser's philosophical, spiritual and aesthetical pilgrimage persistent and constant from the beginning of his life to the end “'(Lang 44). She comes to this conclusion in her analysis of Dreiser's spiritual progress with a focus on The Genius, The Bulwark and The Stoic. Takeda argues that Dreiser's understanding of the inner reality of life is progressive and can be most clearly seen in his last novel The Stoic. In her discussion of the theme of Hinduism, she responds to the often objected introduction of Hindu mysticism in the last chapter of The Stoic. She counters the objection often made by critics that 
the last chapter was actually written by Dreiser's wife Helen, with the assumption that the introduction of Hinduism is a "natural development of Dreiser's search for the ultimate reality, a search that long pre-dates the conclusion of his last novel"(28). Takeda points to Dreiser's strong attraction to and concern with the problem of the absolute Existence and human existence asserting that especially in Dreiser's Notes on Life a strong interest in Hinduism in connection with science and Christianity can be found. The introduction of Hinduism is understood as an intention to make Cowperwood's life more meaningful than Yerkes's life was portrayed to be. Takeda emphasizes Dreiser's uniqueness in his concept of Brahman as the source of beauty and concludes that Dreiserian Hinduism is not a "casual or sudden development in the novelist's thought. Whether or not it might reduce the novel's effectiveness as a literary achievement, whether or not he was influenced by Helen, the theme is a significant and appropriate literary finale for Dreiser. It is the reflection of his comprehensive vision, the outcome of his lifelong struggle to find the meaning of life : Inner Reality" (33). The critic can see Dreiser's spirituality most clearly represented in his last work The Stoic, but it might have been interesting to see if she would have found his spiritual pilgrimage as persistent in such works as The Titan or The Financier. The limitation of this essay lies, as in so many of the following critical works, in the selection of the novels as well as in the attempt to fit Dreiser into some kind of category. Takeda chooses two of Dreiser's last novels which have often been neglected in critical studies. They have often been considered disturbing or in other words, The Stoic and The Bulwark did not fit into the naturalistic genre, so they were simply ignored or questioned for their authenticity because of their posthumous publication. Takeda concludes that the theme of Hinduism is consistent within the canon. This assumption should be 
understood with caution, since Takeda merely focuses on the three above mentioned novels and not on the entire work. Her selection of these novels, with the balance leaning toward the work of Dreiser's final years seems to be made in a premature attempt to support her thesis.

Barbara Hochman in her discussion of Dreiser's last work comes to a similar conclusion as Takeda. Like the previous scholar, she too focuses on Dreiser's last work. In The Stoic the spiritual explorationsof Berenice,the protagonist's last and most influential mistress are seen as part of Dreiser's life-long interest in all possible modes of seeking and striving for material goods, spiritual satisfaction, love, money, nirvana. Hochman states that an interesting aspect of Berenice's odyssey is the peculiar similarity between certain of the Guru's pronouncements, and the assumptions which underlie even Dreiser's earliest novels. The guru's statement ' IIf a man come to your door, go and meet yourself"', she argues could serve as a motto for all of Dreiser's work, with its assumption that the lowest and the highest of human creatures are very much the same (10). She emphasizes that the Guru's counsel to Berenice, like the lessons Solon and Etta learn in The Bulwark, do not constitute a sudden, incomprehensible transformation of all of Dreiser's long-standing beliefs. Dreiser's "conviction of the need to refrain from judgment, his sense of analogy between the primitive and sophisticated, had served over a period of twenty-five years to endow his work with a force and a dimension often lacking in the work of the naturalists with whom he is often still associated" (10). Hochman believes, even though there might not be a serene conviction of Divine design in Dreiser's earlier work, that he assumed the protagonists of his earlier novels were likely to be driven by undefined and irresistible longings like a Cowperwood or a Witla. The quest or impulse toward the divine, however, can be seen in different forms. Dreiser's fiction is seen as 
coherent with the longing for the ideal as the unifying factor. This critical attempt to find spiritual elements in Dreiser's fiction might be a necessary reaction of earlier criticism that tried to see the naturalistic elements in Dreiser's work. Both. Hoch mann and Takeda's approaches tend to be taking extreme standpoints and as a result fail to show the conflict in Dreiser. They cannot identify the real issues Dreiser is concerned about since neither category has space for openness in their interpretation. None of them are wrong, but it does not mean that the whole truth and the core issues have been addressed in the above discussed criticism. What remains useful for my thesis is that they clearly point to the different and conflicting tendencies in Dreiser's work, which is exactly where my thesis tries to find its niche.

The school closest to my approach is marked by critics such as Louis J. Zanine and others. Their explanations differ from the theory of Dreiser's final reconciliation between science and religion by arguing that his fiction represents a retreat into the romanticism of the eighteenth and nineteenth centuries. One critic even attempts to designate Dreiser as a late transcendentalist. This school of criticism often overlaps with the third and second phase. Louis Zanine, for instance basically supports Barbara Hochman's argument and states that Dreiser cannot be categorized as "the archetypal exponent of a bleak and hopeless materialism that characterized American naturalist thought in the late nineteenth and early twentieth centuries" (2). He argues that the stream of recent criticism has acknowledged Dreiser's spiritual quest for knowledge about life and the universe which was based on an intense desire to achieve some sort of spiritual peace. Zanine explains Dreiser as a writer "trying to reconcile the newly developing authority of science and the more traditional influence of religion that most had absorbed his youth" (2). This scholar examines Dreiser's interest in modern 
scientific research and the impact of scientific ideas on his thought and work. He argues that Dreiser's immense scientific interest "was primarily a religious quest to find emotionally and spiritually satisfying answers to questions about human purpose and destiny that had traditionally been addressed by orthodox religion" (2). Ideas of evolutionary theories and Dreiser's conceptualization of the evolutionary universe provided the framework in which his characters move and act in his early fiction. The author discusses Dreiser's attraction to the supernatural through various personal experiences that science was not fit to explain. In 1937 Dreiser experienced a kind of spiritual Epiphany in which he was able to intuit a "Divine Being's" presence in all nature. Dreiser's last eight years are examined intensely in this study, which reveals how in this period of his life he relied less on the testimony of modern science as a sanction for his philosophical speculations and more on the testimony of his own feelings and emotions to find the nature of God and the meaning of life. Zanine discusses Dreiser's study of mystical philosophies and religions such as Transcendentalism, Quakerism, and Hinduism to enlarge his intuitive vision. Ultimately Dreiser's final reconciliation between science and religion is explained by Zanine as a retreat into the romanticism of the eighteenth and nineteenth centuries.

As mentioned earlier, a classification into a historical context does not necessarily contribute to a better understanding of the critical response. Richard Lehan for instance discussed the theme of romanticism some thirty years before Zanine in his essay entitled "The Romantic Dilemma". Lehan believes that Dreiser's use of Spencer's ideas led him into the romantic dilemma. On the one hand Dreiser maintained that "man is 'incurably romantic' and that 'it is only by acting in the name of. .. an ideal that ... [the ideal] is brought to pass"' and on 
the other hand that man could not fulfill his ideals because "'at his best he is a product of heat and gases generated in amazing variety by so infinitesimal a thing as the sun' and that man is born 'to desire which he has not' "(137). Lehan notes that Dreiser's inability to reconcile his romantic ideas with a physically limited world, led to the displaced hero in his fiction, a character who desires for self-fulfillment in conflict with his environment. Dreiser is described as a believer in man as a creature of illusion, longing for the ideal in a world where force and circumstance cancel out ideals. This dilemma, man's insignificance in the face of time, his inability to hold onto the present moment and the impermanence of man, run through romantic poetry, and Dreiser was as overcome by these themes as a Shelley or Keats. The theme of man's limits or the romantic dilemma according to Lehan can be found in all of Dreiser's characters and novels. This is why Dreiser told the complete story of Frank Algernon Cowperwood, from birth to death. Dreiser's characters are seen as victims of the romantic dilemma "their genius was negated in the play of forces; their aspirations were in conflict with time; and their ideals were in conflict with society" (141). Both scholars, Zanine and Lehan, acknowledge Dreiser's aspirations to romanticism in his attempt to reconcile scientific ideas such as Spencer's evolutionary theory and the idealism of romanticism. Zanine's emphasis is on the merging of science and religion whereas Lehan omits a discussion of religious influence in Dreiser and shifts his emphasis to ideas of the romantic period, which might also be of a divine origin.

Yet another trait in Dreiser's writing seems to be represented in an essay by Roger Asselineau entitled "Theodore Dreiser's Transcendentalism". Similar to Lehan's attempt to find romantic traits, this scholar believes he sees transcendentalist ideas and thought in Dreiser's literature. Asselineau argues 
that to position Dreiser in American literature as a naturalistic novelist is a very "hasty conclusion" (92). In the critic's opinion Dreiser is a compound of two hemispheres, one of which is invisible and another hidden, a generally neglected hemisphere except by such critics as Alfred Kazin, F.O. Matthiesen and Charles Walcutt, namely his transcendentalism. These two notions, though apparently contradictory are seen as a constant factor in Dreiser's work. For the poet there was no inconsistency in "describing psychological and social phenomena from a materialistic standpoint with the detachment-and sometimes the jargon-of a scientist, while at the same time expressing the wonder of a child or poet before the mystery of life" (92). Asselineau illustrates his point by numerous textual examples from works by Dreiser such as $\underline{A \text { History of Myself }} \underline{\mathrm{A} \text { Traveler at }}$ Forty, and compares them with transcendentalist poetry, finding many analogies. From the textual analysis, the scholar concludes that Dreiser mystically understands God as part of himself, the boundaries between man and God merging, combined with a "disquieting sense of the purposeless and meaninglessness of the world ... " (94). Much like Emerson, Dreiser is seen as transcending his doubts, although never able to entirely discard them. $\mathrm{He}$ embodies a transcendentalist worshipper of "'the hidden God', 'the substance of suns, and flowers, rats and kings'" (95). His apprehension of beauty, all forms of life, and the enigmatic force which carries all things forward toward an unknown destination is a mystical intuition or a form of religious worship. Asselineau asserts Dreiser's belief in destiny or an "over or one universal soul" (96), except that Dreiser replaces this "oversoul" with energy as conceived by modern physics. More evidence supporting Asselineau's thesis of Dreiser's transcendentalism is compounded by the writers interest in and use of Hinduism in one of his novels and his compilation of a book entitled Thoreau's Living 
Thoughts , of which Dreiser said that:"' I felt . . . that I had gotten together a body of real thought most valuable to me if no other'“ (98). In concluding, however, Asselineau warns of an exaggeration of the importance of transcendentalism on Dreiser's work in an effort to put that influence into somewhat of a true proportion. For Asselineau, Theodore Dreiser, would have been a dull naturalistic writer, depicting American society in a photographic fashion, without the transcendentalist element. His strength, according to Asselineau is in his ability to sense "beneath this world of appearances another inward world which he kept wondering at and whose universal presence conferred beauty and mystery on the most banal and insignificant sights" (102).

Another major scholar who discusses the theme of Dreiser's conflicting ideas and who asks such questions as :"How was Dreiser able to say in The Financier and The Titan that living in society is like living in the jungle and scarcely twenty years after insist that society is not and should not be a jungle?" (Preface 9) is Robert Elias. The material this critic uses to support his thesis is mainly derived from letters written by Dreiser, radio interviews, conversations and essays by Dreiser. The actual novels are discussed only marginally, which can be seen as one of the major limitations of this critical study. Elias describes the various influences of ideas by Herbert Spencer, Balzac and the impact these ideas had on Dreiser's world view. It seems to me especially interesting to note that whatever idea or philosophy Dreiser was interested in at various stages of his life, he never seemed to be satisfied with any of the existing philosophies. The letters and opinions Elias uses for his book might be viewed as a reflection of various of Dreiser's preoccupations and present concerns with philosophy, but I am inclined to be careful in taking this material as Dreiser's deepest beliefs-down true belief, which can be more clearly identified in his novels. The art-form of 
fiction is able to sustain different levels of meaning, giving them form in characters and a fictitious world, that transcends the exchange of communication in the form of letters or interviews.

The first two books of Dreiser's "Trilogy of Desire" are discussed in the chapter entitled "Survival of the Fittest", indicating the category under which Elias examines these two novels. He senses a conflict in Dreiser's alleged naturalism. The incident of the lobster devouring the squid in an aquarium at the beginning of The Financier which young Cowperwood watches attentively, might illustrate life, but Elias shows that lobsters did not always win. The scholar states that "it was not in the actual struggle or illusion that values lay, nor in the fact of potential equilibrium, but rather in the awareness and appreciation of what struggle, illusion, and equilibrium meant" (174). Dreiser, unable to answer the questions of life with mechanistic philosophies turns toward the forces that operate in the "deeps of space"(178). This is explained as a shift of emphasis from the terror and wonder of the individual toward the forces to "which all individuals are subservient" (178). This force seemed to indicate something that couldn't be explained. Dreiser says "Life is what it seems" (288) and the "illusions of value which make up the cycle of our life must be necessary and evidently are functional to some other end, unknown to us" (289).

I have shown the basic tendencies in Dreiser criticism as a way of introducing my approach to the following chapters of this thesis. Beginning with the camp of critics which tries to categorize Dreiser as the bleak agnostic and naturalist to the counter-reaction of the school of critics following the same fashion of categorization yet with an emphasis on the other extreme of the spiritual and mystical elements in Dreiser's work. The third school of critics is characterized by its more complex approach of recognizing conflicts and splits in 
Dreiser literature. None of these critical approaches, however, discuss how the division between the material and the spiritual has been dramatized in the books Dreiser has written. My thesis will scrutinize and demonstrate that conflicts in Dreiser criticism reflect unresolved conflicts between these issues in his "Trilogy", a collection of three novels entitled: The Financier (1912), The Titan (1914) and The Stoic (1947). With the help of the criticism that I have discussed in this chapter I have detected a division between material and spiritual issues that dramatize through three main strategies throughout the "Trilogy". They are discussed in the following three chapters entitled: Finance, Art and Women. I understand Dreiser's strategies as an effort to bridge the division between the material and the spiritual; whether it is successful or not will be answered during the course of this thesis. My approach will give a fresh view on Dreiser's "Trilogy" by transcending the traditional categorization of Dreiser criticism to come to a more complex understanding of the core issues of his writing. 


\section{Chapter Two}

Finance

The young Cowperwood of The Financier is not only described as a "financier by instinct", but more importantly as a person to whom "all the knowledge that pertained to that great art was as natural as the emotions and subtleties of life are to a poet" (Financier 11). Dreiser's financier is a man whose interest in money goes beyond material considerations; to him finance is an art. I will discuss the credibility of this theme and its possible implications for the conflict between the spiritual and the material.

Since Frank Cowperwood's father is in the banking business, it seems natural for the young Cowperwood to aspire to his father's career. He wins his father's approval when he makes his first profit with the local grocery owner by trading soap. Later we gain more insight into what motivates Cowperwood's interest in money. When his visiting uncle, who made his fortune in Cuba, asks his nephew about his interests, Frank's answer is brief and decided: "Money". At the marriage to his first wife, Lillian Semple, he contemplates the fact that their combined finances suggest an opportunity to greater wealth, "He was going to work hard for his money. With his means and hers now at command, he might become, very readily, notably wealthy" (Financier 55). So it is wealth and power, "his total perception is of power" (Financier 235), that mark this man's primary goal in the acquisition of 
money, and the power money would give him provides the answer to his deepest call , "I satisfy myself."

Cowperwood's self satisfying motto combined with his talent account for a personality that goes beyond "a sense of wealth as it is ordinarily understood" (Financier 235). The narrator tries to convey the theme of finance as an art, but we are put into the uncomfortable position of having to reject Dreiser's explanation of Cowperwood's special relationship to money. Cowperwood is depicted as a man who functions without conscience in gaining power and self-satisfaction; finance as an art seems a theme which is pushed by the narrator rather than a quality that the protagonist embodies:

... It was an illegitimate gain, but his conscience was not very much troubled by that. He had none truly. He saw visions of a halcyon future. It is difficult to make perfectly clear what a subtle and significant power this placed in the hands of Cowperwood ... Imagine yourself by nature versed in the arts of finance, capable of playing with sums of money in the form of stocks, certificates, bonds, and cash, as the ordinary man plays with checkers or chess. (Financier 99)

Dreiser takes considerable pains to establish the notion that finance can be seen as an art, to make acceptable that Cowperwood, though largely motivated by his desire for power, would also see finance as a means of pursuing aesthetic appreciation. This would then establish a connection to the two other main themes of the "Trilogy", namely Cowperwood's responsiveness to feminine beauty and his appreciation for art, which I will discuss in more depth in the following chapters. However Dreiser does not succeed in fictionally connecting these themes; thus the "Trilogy" somewhat awkwardly breaks down into sections that alternate between the subjects of finance and love. While it might be argued that this separation is intended by Dreiser in 
order to contribute to the tension and conflict in Cowperwood between his life in the world of finance and his pursuit of beauty, no matter how this division is interpreted, it clearly indicates the existence of two seemingly irreconcilable character elements in Cowperwood. Donald Pizer comes to a similar conclusion: "Dreiser wishes us to believe that Cowperwood has two lives, that of the world and that of the spirit- that of the 'mailed knight' and that 'of the cloudy realm of beauty" (Pizer 172).

The Cowperwood we learn about in the first novel of the "Trilogy" is characterized as a man whose main goal is to succeed in a hostile world that is best described by the lobster-squid passage at the beginning of The Financier. As he watches the lobster devour the squid, young Cowperwood sees an answer to his question of how life is organized: "Strength would win- weakness lose" (Financier 241). This Cowperwood, who functions on the level of the animal world, shows a lack of conscience or compassion for the weak. Like the lobster driven to survive, Cowperwood is not troubled by "That thing conscience, which obsesses and rides some people to destruction, ... . He had no consciousness of what is currently known as sin. There were just two faces to the shield of life from the point of view on his peculiar mindstrength and weakness" (Financier 240).

Cowperwood's character points toward the man whose wealth would later go beyond the ordinary perception of wealth. Juxtaposed with Cowperwood's Darwinian approach to business in the "Trilogy," two characters illustrate the rather unsuccessful alternative. Cowperwood senior, the banker who slowly but steadily moved forward, demonstrates the danger of a financial career based on caution, honesty and virtue, but lacking his son's strength and guile. He is destroyed by the panic of 1871 and never recovers. 
Falling into deep depression, he loses his former position and retreats into painful obscurity: "Cowperwood, senior, had sufficient money wherewith to sustain himself, and that without slaving as a petty clerk, but his social joy in life was gone. He was old, disappointed, sad. . . His courage and his dreams were gone, and he awaited death" (Financier 445). Stener, Cowperwood's assistant in the city council, on the other hand represents the immoral dishonest character without the strength of Cowperwood: "Stener was lacking in force and brains-not morals. This lack was his principal crime" (Financier 200). Stener is small-minded and when under pressure reveals himself as a coward; like Cowperwood senior, Stener also fails to succeed financially.

Some critics, among them Pizer, have argued that Cowperwood undergoes a change from the person he is in The Financier to the one we meet in The Titan. Pizer states that the Cowperwood in The Titan "is endowed with a speculative insight into human nature and experience" (Pizer 189) and goes on to say that Cowperwood "thus has the distinctively Dreiserian attitudes of compassion for the victims of life's inevitable destructiveness and of responsiveness to the beauty of the uncontrollable and destructive flux which is life (Pizer 189). However I could not find any proof for this claim since almost without exception Cowperwood's financial deals are devoid of compassion for the public or concern for the socially weak. In The Financier Cowperwood realizes for the first time that he has become a significant financial figure in Philadelphia:

... his star had been so rapidly ascending that in the helter-skelter of great and favorable events he had scarcely taken thought of the social significance of the thing he was doing. Youth and the joy of life were in his blood. He felt so young, so vigorous, so like new grass look and feels. The freshness of spring evenings was in him, and he did not care. (Financier 349) 
Though Cowperwood realizes the social significance of his success, (with his financial power literally thousands of people's fortunes rise and fall), he is not even marginally concerned for anybody except himself, " . . even now, the beauty and delight of a girl like Aileen Butler, were far more important to him than the good will of fifty million people, ... (Financier 349). The first time Cowperwood seems to question his goal of wealth and fame is after his imprisonment in the Philadelphia penitentiary for the embezzlement of city loans. Here, without any of the financial activities that had so far preoccupied his mind, Cowperwood begins to put his own life, the ego that means the center of the world for him, into relation with the "... soundless depth of space, ..." (Financier 417). While astrology gives inspiration to his contemplation in the Eastern penitentiary it dawns upon him that "his own life appeared very trivial in view of these things, and he found himself asking whether it was really of any significance or importance" (Financier 418). Ironically Cowperwood, though beginning to question his purpose in life, seems unable to take the step into actively changing directions in his life. Cowperwood's feels ambivalent about leaving the penitentiary after six months of imprisonment:

... At the entrance of the prison he turned and looked back-one last glance-at the iron door leading into the garden 'You don't regret leaving that, do you Frank?' asked Stener curiously. 'I do not' replied Cowperwood. 'It wasn't that I was thinking of. It was just the appearance of it that's all. (Financier 433)

The word "iron" is used numerous times describing Cowperwood's iron will, his iron personality and iron mind; in this instance the iron door of his will seems to keep him from entering the garden, which is often associated with 
the heart, but more so with the garden of Eden and hence the biblical Paradise. Cowperwood appears to be thoughtful at the appearance of the iron door-garden image, probably as an indication that he did, even if only for a short time, take his mind from the world of finance to envision the unknown world behind the iron door, symbolized by the garden.

Although Cowperwood voices thoughts about the insignificance of his deeds in contrast to the vast universe, his imprisonment does not result in a growing consciousness or an insight into the nature of his own personality.

On the contrary the Cowperwood who leaves the penitentiary is just as much concerned about achieving his vision of fame as the financier who shortly before stated that "There was no more escaping the greatness that was inherent in him than there was for so many others the littleness that was in them" (Financier 418). Cowperwood's punishment not only reinforces his old motto of self-satisfaction but teaches him the importance of outwitting the system that once was able to convict him of crime.

... 'If I get out of this safely,' he said to himself, 'this is the end. I am going West, and going into some other line of business,' He thought of street-railways, land speculation, some great manufacturing project of some kind, even mining on a legitimate basis. 'I have had my lesson,' he said to himself, finally getting up and preparing to leave. 'I am as rich as I was, and only a little older. They caught me once, but they will not catch me again'. (Financier 444)

There are no signs of remorse, quite on the contrary, a buttressed motivation to accumulate even more wealth. In fulfillment of the American frontier spirit, Cowperwood and Aileen decide to move from Philadelphia to Chicago, rejecting the closed social world and its restricting moralism. They go west to find greater financial as well as social freedom. 
The Titan tells the story of an even more financially successful and therefore more powerful Cowperwood. He has "learned" from his first business failure in Philadelphia. Now more aggressive and with an iron will, the financier vows to make his ascent to the top without any dangerous business partners hindering this path such as the cowardly Stener who had, among others, led to Cowperwood's failure: "He could, should and would rule alone. No man must ever again have the least claim on him save that of a suppliant" (Titan 32). Again, I would disagree with Pizer's assertion that Cowperwood gains in both compassion and appreciation of "the uncontrollable and destructive flux which is life" (Pizer 190). Though Cowperwood in The Titan does gain more insight into human nature and life through experience, it does not result in an attitude of benevolence and compassion toward the public. If anything, it results in a hunger for power: "If through luck and effort he became sufficiently powerful financially he might then hope to dictate to society" (Titan 32).

Cowperwood's deep desire for absolute power over society conflicts with the Dreiserian compassion Pizer refers to. The financier feels "sympathy with the mass more than with the class, and he understood the mass better" (Titan 32). Not only do these lines describe the two different forces in Cowperwood--his search for power on one side and human compassion for the victims of his power on the other--they also illustrate the gap between the narrative voice (The narrator wants the protagonist to be compassionate and expanding his consciousness for the public) and the actual evidence that would support these traits.

Cowperwood's donation of a $\$ 300,000$ telescope to the University of Chicago is a poorly masked, though successful attempt to bribe the mass into a 
more positive attitude toward the ruthless financial titan. His true character shows in the notorious failure to contribute anything beneficial to the masses. Though the building of public transportation in Chicago and London leads to an improved and extended city transportation system, his main intention is still wealth and the subsequent power over the material world. Cowperwood's belief in money's power to solve almost any problem is unaltered, "I haven't seen many troubles in this world that money wouldn't cure" (Titan 65). The logical consequence of such an insight would have been to solve social troubles with his tremendous financial resources, but Cowperwood neither voices nor attempts such an idea. The only exception is during his final days shortly before his death, though his will remains unfulfilled in reality.

With the introduction of Berenice Fleming, the pinnacle on the scale of women representing stages in Cowperwood's evolution, the financier begins to see the futility of his financial ventures: "It suddenly came to Cowperwood, with great force, how comparatively unimportant in the great drift of life were his own affairs when about him was operative all this splendid will to existence, as sensed by her" (Titan 358). In spite of his insight into the futility of his work-an insight that should move him to a perception of the importance of the world outside himself-he seems to remain egocentric. In fact one of the most ambitious struggles, the attempt to obtain and extend his railroad franchises in Chicago to gain total control of public transportation, illustrates most vividly the conflict in his character, a conflict between his attempt to compensate spiritual emptiness with ever more challenging financial enterprises and his developing realization of a world beyond materialism, as suggested by Berenice Fleming. 
The Titan marks more than the climax of Cowperwood's business career by acquiring the majority of the London underground system; the end of The Titan shows an important shift from the detailed and sometimes tediously minute descriptions of the financial world toward philanthropic and spiritual issues. The Cowperwood of The Titan becomes a truly titanic figure: his financial power is at its peak and he owns holdings and profitable investments in "a half-hundred companies", but his goal changes. He confesses to seeking an ideal which he believes he can find in a woman :"My ideal has become fixed, though, apparently, I have had it for a number of years now. It spoils other matters for me. There is such a thing as an ideal" (Titan 422). Whereas in The Financier Cowperwood merely seeks money, wealth and fame, in The Titan he asks:

... What after all, were life, wealth, fame, if you couldn't have the woman you wanted-love, that indefinable, unnamable coddling of spirit which the strongest almost more than the weakest crave? At last he saw clearly, as within a chalice-like nimbus, that the ultimate end of fame, power, vigor was beauty. (Titan 426)

For a considerable time during The Financier and The Titan the pursuit of women and art (quest for beauty) equal his desire for fame and power. The end of The Titan reveals Dreiser's and Cowperwood's evolution from the pursuit of worldly gain toward the involvement and influence supported by the spiritual and philanthropic experiences of Berenice Fleming.

The Stoic differs from the two earlier discussed novels in that it contains less detailed accounts of Cowperwood's financial dealings. His struggle in obtaining the London underground, for instance, is given considerably less emphasis than similar business issues had received in the previous novels of 
the "Trilogy". The world of finance, once so belabored and detailed is displaced in The Stoic by the emphasis on the spiritual.

Cowperwood, who realizes his old-age, does not appear to have changed with the fictional change of emphasis. He still follows his selfsatisfying view of life, though a slight change is indicated by the more differentiated use of language, pointing toward frustration, bitter attitude, "Intelligently or unintelligently, I try to follow the line of self-interest, because, as I see it, there is no other guide'" (Stoic 4). Aileen tellingly describes her husband with the phrase, 'He'll keep on working until he dies, ... '“ (Stoic 148). Cowperwood is unable to overcome his greed, though having already acquired everything money can buy, "He [has] created fame and wealth for himself "(Stoic 106). Ironically he still gains the same excitement from his financial affairs as he did in earlier days, always looking for new challenges, for new ways of making money, similar to his pursuit of women.

The financier's ability to reflect on life and his larger vision are a development increasingly emphasized in The Stoic paralleling his addiction to wealth. When talking to his business advisor, Cowperwood realizes once more the ironic inconsistency of his excitement opposed to the insights he has gained about the finality of life and his goals in work. The result of his work and the plans he now pursues become futile in light of the amount of wealth and fame he has already achieved. Cowperwood knows that he has reached the peak of his life as he speaks with irony to De Sota, his business advisor in the London underground venture: "Here we are, you and I, both of us getting along in years, and now running around on this new job, which whether we do it or not, can't mean so much to either of us. For we're not going to be here so much longer, De Sota, and neither of us needs the 
money'" (Stoic 120pp). De Sota responds to Cowperwood's insightful question, "What astonishes me is that we can get so excited over it. Aren't you a little astonished at yourself?"“ (Stoic 121) thus formulating, that life and their pleasure from business is comparable to a sort of a game where people merely play their parts. The answer to life according to De Sota can be found in "doing something all the time. There's a game on, and whether we like it or not, we have to play our parts" (Stoic 121). Dreiser's insistence on seeing finance as an art becomes more acceptable in the light of Cowperwood's later attitude toward business. The argument that he is no longer interested in fame or wealth appears credible and therefore we can accept a motivation that originates beyond material compensation. Like the "true artist" who ideally loves art for art's sake, Cowperwood in The Stoic demonstrates an aesthetic understanding of finance. The paradox is comprised in recurring signs of fatigue of Cowperwood's business affairs parallel to his steadily growing desire for peace and rest. After returning from the Norwegian trip, Cowperwood not only appreciates the recreation this voyage had given him, but also contemplates the materially simple lifestyle of the natives with a sense of melancholy desire for this seemingly fulfilling life. A further inconsistency of the theme of finance as an art emerges out of Cowperwood's assertion that his preoccupation with finance has " . . barred him from knowledge of the intellectual and artistic significance of genius in many other fields" (Stoic 242). If finance were truly an art, Cowperwood should have gained "knowledge ... of the artistic significance of genius".

The Stoic follows the pattern of other novels by Theodore Dreiser, where one character rises while another falls, or where certain notions in a single character rise and fall, as in Sister Carrie. Cowperwood has reached the 
point in his life, where his goal of fame and wealth has been reached, yet he is compelled to keep working, despite Berenice's advice to rest for his health. Cowperwood becomes the victim of his own mind: the iron will that once enabled him to attain such a powerful position, now hinders him from reaching a peaceful equilibrium. The mind, an invaluably useful tool in his financial career, now hinders his spiritual growth: "The mind! The mind! If he could only mentally, as well as medically, influence his mind to come to its own rescue! "(Stoic 285). In the light of mortality and an abundance of money, Cowperwood's work is now empty and useless. The once superior financier declines, his health and business- affairs become comic and contradictory, since they lack any real significance to the public or himself. Cowperwood has become one of the wealthiest men in the United States, but only a few years after his death the millions have disappeared like a dream. It was his strong personality, his will to keep accumulating possessions that kept his financial empire together; after he is gone, Aileen cannot fight against the vultures that are interested in making a profit out of Cowperwood's death by legal means, ownership rights, auctions etc. The conflict between the material and the spiritual remains unresolved. The obsessive pursuit of fame and wealth appears like pursuing a ghost, an image of the imagination that can never be grasped. With Cowperwood's death not only do his possessions vanish but also his dreams of making an art museum out of the Fifth Avenue mansion and a hospital out of his enormous heritage.

The protagonist's death would have been a logical ending of the "Trilogy". The story of Berenice in the final chapters seem like a strategy to resolve Cowperwood's profound questions, an attempt to reconcile the material with the spiritual. In her travel to India Berenice finds satisfaction 
with the guru's spiritual wisdom and a life devoted to giving, a guideline and a goal Cowperwood was unable to find. With the help of the guru in India Berenice renunciates materialism and a life centered solely on the self. The final chapters of The Trilogy refute " ... the whole Western materialistic viewpoint which made luxury its only god" (Stoic 307). But Dreiser does not condemn living in the material world. Quite on the contrary, he expresses the concern that spiritual attachment to the material world consequently will lead to suffering. The guru explains "... The man who gives up living in fine houses, wearing fine clothes, and eating good food, and goes into the desert, may be a most attached person" (Stoic 312); The message is that we don't have to change the material world, but rather our perception of it, in order to reach the level of true non-attachment. Unlike Sister Carrie who sits in her rocking chair, in a statically moving but not evolving state, Dreiser takes Berenice one step further. When Dreiser was unable to resolve Cowperwood's struggle, he attached an ending to the "Trilogy" that apparently resolves the questions and conflicts he was unable to resolve in the protagonist. I cannot but dismiss the clichéd statements expressed through Berenice's experiences with the Indian guru that give answers and quick resolutions to the complex issues Cowperwood is associated with. The ending of the "Trilogy" illustrates Dreiser's romantic urge for closure--and for resolution of the questions he has raised in the "Trilogy". However, the answers the last chapters provide us with are given to a different question, in the form of another person (Berenice) in a setting that Cowperwood has no connection with. 


\section{Chapter Three}

\section{Art}

In this chapter I will discuss Art as a another possible strategy to reconcile the material/spiritual conflict in Dreiser's "Trilogy". As a first step of this strategy Dreiser gives a redefinition of the term "artist" with the introduction to a Cowperwood who shows an early interest in traditional arts, such as painting and architecture". The "Buying and selling of stocks, as [Cowperwood] soon learned, [is] an art , a subtlety, almost a psychic emotion"(Financier 42).

Consistent with the presentation of finance as an art, Cowperwood himself is depicted as an artist. The financier uses different means and "tools" to create a piece of art, comparable to a poet or a painter, his creations being the railroad lines of Chicago, his business building, the later Fifth Avenue mansion in New York, (erected mainly for his art collection), the underground lines in London and eventually his own tomb.

When looking at the busy streets of Chicago, the financier sees the world through the eyes of an aestheticist sensing the beauty of city life: "... the two sides of the city ran this amazing stream-dirty, odorous, picturesque, compact-of a heavy, delightful, constantly crowding and moving boat traffic, ... It was lovely, human, natural, Dickenesque-a fit subject for a Daumier, a Turner, or a Whistler" (Titan 157). Apparently Cowperwood prefers to practice his artistry on urban America, on the pavements of growing cities rather than in nature. But not only does the narrative voice characterize Cowperwood as a person with 
artistic potential and aesthetic sense, numerous other characters reflect his artistic personality. Stephanie Platow, one of Cowperwood's mistresses conceives of him "... as a very great artist in his realm rather than a businessman, and he grasped this fact after a very little while and appreciated it" (Titan 199). Aileen sees in her lover a "... man who would rise beyond anything he now dreamed of-she felt it. There was in him, in some nebulous, unrecognizable form, a great artistic reality which was finer than anything she could plan for herself" (Financier 145). Berenice and Cowperwood have "... one god in common-Art" (Titan 401).

With the creation of Dreiser's artistic financier, the author emphasizes that Cowperwood cannot be understood without taking art into account. Finance and art do not seem to exclude each other in Dreiser's viewpoint, he does not place one as more honorific than the other. Cowperwood's speculation with money, his career as a financier is not reduced to mere materialism but contains the idea of aesthetics: "We think of egoism and intellectualism as closely confined to the arts. Finance is an art" (Financier 120). The narrator attempts to reconcile the gap or separation often made between business (the material world) and art (with its spiritual connotation). The struggle of coexistence of the material and the spiritual is later taken up again after some thirty years with the guru's teachings in The Stoic. The guru teaches Berenice a lesson on nonattachment. As an answer to her ideas to give up worldly things in order to rest her spirit, the guru replies:

... The man who gives up living in fine houses, wearing fine clothes, and eating good food, and goes into the desert, may be a most attached person... In truth, non-attachment does not mean anything that we may do in relation to our eternal body. It is all in the mind. A man may be on a throne and perfectly non-attached; another may be in rags and very much attached. (Stoic 312) 
In Dreiser's special brand of Hinduism voiced by the guru, he takes up the same subject of the spiritual/material conflict, claiming the possibility of peaceful coexistence of worldly possessions alongside spiritual life.

Cowperwood's creativity and his aesthetic sense are at the core of his projects and financial ventures. As a young man, following his marriage to Lillian Semple, one of the first actions Cowperwood takes is the artistic remodeling of his wife's house. His obvious dissatisfaction with the objects of art she and her former husband have arranged in their home, displays the importance of art in his life. " . . the artistic impressiveness, as to the furniture at least, was wanting, although it was new and good. The pictures were-well, simply pictures" (Financier 43). The artistic taste of the young Cowperwood seeks more than just practical furniture or mere reproductions of reality without any artistic value. He objects,

$\ldots$ at once after they were engaged to the spirit of the furniture and decorations, or lack of them, and had suggested that he be allowed to have it brought more in keeping with his idea of what was appropriate. During the years in which he had been growing into manhood he had come instinctively into sound notions of what was artistic and refined. (Financier 55)

In fact, Cowperwood spares no expense to express his desire for art and hires Wilton Ellsworth, an architect who is described as an ". . . artist in spirit, quiet, meditative, refined" (Financier 56), and at the same time as a reflection of Cowperwood's artistic personality and his vision of an architect who would be fit to remake Cowperwood's residence. Ellsworth revises the cost of remodeling the house including the furniture, which amounts to an estimated three thousand 
dollars. This house and its artistic alterations constitute only the beginning of Cowperwood's desire to express his connoiseurship of art.

Some years later, the financier's successful career allows him to construct an impressive bank building for his prospering business, named Cowperwood \& Co.. The narrator goes into great detail describing the artistic features of the bank building in order to emphasize Cowperwood's steadily growing interest in and his expression of aesthetics and beauty in the form of architecture. The bank building features details such as its artistic decoration " . . e early Florentine in its decorations with windows which grew narrower as they approached the roof, and a door of wrought iron set between delicately carved posts, and astraight lintel of brownstone" (Financier 95). Simultaneous with the building of the bank, Frank Cowperwood and his father join to build two representative residential homes side by side. The young financier experiences the process of designing his mansion, the rooms and the furniture in period styles as:

... very significant in that they enlarged and strengthened Frank Cowperwood's idea of the world of art in general. It was an enlightening and agreeable experience-one which made for artistic and intellectual growth-to hear Ellsworth explain at length the styles and types of architecture and furniture,.... (Financier 96)

The erection of these two buildings (the business house incorporates elements of imperial Rome and of Venice in the resplendent days of the Doges) expresses Cowperwood's desire to display power and good taste and constitutes the beginning of Cowperwood's standing on a different level, materially and aesthetically, a position superior to and outside of society: "And when the houses were finished, they were effective and arresting-quite different from the conventional residences of the street" (Financier 95). Shortly after the description of the Cowperwood's new home the narrator interjects this rather unusual observation: 
... The effect of a house of this character on its owner is unmistakable. We think we are individual, separate, above houses and material objects generally; but there is a subtle connection which makes them reflect us quite as much as we reflect them. They lend dignity, subtlety, force, each to the other, and what beauty, or lack of it there is, is shot back from one to the other as a shuttle in a loom, weaving, weaving. (Financier 98)

The reflection of material objects on their owner, in this case a beautifully constructed residence, might be a well-known concept, however to assume that "we reflect them" also raises the question of such an effect on its owner. The symbiotic relationship such as described here suggests that the qualities are in fact projected onto their owner. Hence Cowperwood in his desire to surround himself with beautiful objects of art and his construction of aesthetic architecture puts himself into a mutual relationship with art, where the effect of art on the owner and vice versa enhances his spiritual growth.

When Cowperwood plans on erecting a museum-like mansion on Fifth Avenue in New York, art increasingly seems to be associated with a place of death rather than life. Whereas his family house and the business building in Philadelphia are primarily erected for practical reasons, even though they markedly displayed their owner's great admiration for art and superior position, the Fifth Avenue mansion amounts to, ". . little more than a museum ...." (Titan 401), a place where art is put to rest at peace, confined, locked up for display. And in fact we find Cowperwood's mansion often deserted, housing only the neglected and lonely Aileen, while he spends a great deal of his time on journeys to Europe and especially London where he plans to take over the London underground system. The mansion is dominated by the enormous art collection in the west and east wing of the building. Its interior is richly decorated with the finest woods, silks, tapestries and marble and the heart of the mansion is formed 
by a "great central court with a colonnade of pink-veined alabaster, and in the center there would be an electrically lighted fountain of alabaster and silver" (Titan 399). Rather than being built for practical use, the mansion serves as a memorial building, a mausoleum for Cowperwood's great love of art. His biggest, most expensive and artistically impressive building materializes the financier's vision of appreciation for art as well as architecture combined with his desire for immortality voiced in his wish that after his death others may join his great love for art, "Perhaps others may enjoy it if I do not" (Titan 401).

I agree with McAleer (116) that the creation of these beautiful buildings mean a renewal of happiness for Cowperwood. The buildings also form a link between life and death, the thisworldy and the otherworldly, as I have indicated above in Cowperwood's desire to preserve his art-collection posthumously. Cowperwood's last and final architectural creation is the tomb where he wishes to be buried, "Suddenly there flashed into his mind the idea of a tomb for the two of them [Aileen and Cowperwood], a beautiful and enduring resting place. Yes, he would employ an architect, secure designs, he would build a beautiful tomb ..." (Stoic 243). The tomb manifests Cowperwood's desire for self-presentation as well as his quest for immortality in art and beauty. At the sight of the tomb Aileen is ". . again and finally impressed by her husband's power of selfpresentation" (Stoic 292). People who see the tomb for the first time are described as overwhelmed by the" ... severely impressive artistic achievement in the manner of design, for its tall and stately serenity seemed to dominate the entire area" (Stoic 292) Cowperwood states that, "' . . this tomb, . . will last for a thousand years, ..." (Stoic 275). This tomb represents an attempt to reconcile the material aspects of art (the building, its impressiveness, self-presentation), his desire for creativity and the metaphysical desire for eternity materialized in the 
artful construction of the tomb. In other words, even though his creations in the form of buildings are firmly grounded in material reality, it is ". . the spirit of art that occupied the center of Cowperwood's iron personality, ..." (Titan 399), referring to the aspects of Cowperwood's character that transcend the material world.

So far I have discussed Dreiser's creation of finance as a form of art, Cowperwood's artistic character traits, his sense of aesthetics and the beauty of art as a search for happiness, immortality and a reconciliation between the material world and the spiritual. Large portions of "The Trilogy of Desire" have been devoted to Cowperwood's connoiseurship and his art collection. In fact one of the reasons Dreiser chose to model his protagonist after the real figure of Charles T. Yerkes was his famous art collection and appreciation for paintings and other objects of art.

Cowperwood's acquisition of art is best described at the beginning of The Financier:

... One of his earliest and most genuine leanings was toward paintings. He admired nature, but somehow, without knowing why, he fancied one could best grasp it through the personality of some interpreter, just as we gain our ideas of law politics through individuals. (Financier 60)

This explanation of Cowperwood's leaning toward painting, offers an interesting viewpoint about the nature of his appreciation and understanding of art. As we are told Cowperwood admires nature, however his appreciation seems to be on a different, more spiritual level, namely through the eyes of the artist, an interpreter. The artist's intent is not to give a reproduction of nature, but rather his interpretation of the world, very much like a poet or novelist. Therefore Cowperwood's leaning toward painting can be seen as his to bridge the gap be- 
tween the natural world and the spiritual world. McAleer sees Cowperwood's growing interest in gathering valuable objets d'art as a bond by which Cowperwood lashes himself to Nature. Only in Cowperwood's "... passion for beauty does hope exist that [he] will some day let go his hold on materiality, seeking, if not knowledge, then a kind of comfort found neither in wealth, nor fame nor power, but in the mothering embrace of beauty" (McAleer 114). I find this statement basically true, however I would like to expand on this subject and give a more complex understanding of Cowperwood's quest.

In The Financier, the protagonist speaks of a downfall, a ruin while he is shopping for paintings:

... 'You'll make a convert of me yet, Fletcher,' replied Cowperwood. You or art will be my ruin of me. I'm inclined that way temperamentally as it is, I think, and between you and Ellsworth and Gordon Strake'-another young man intensely interested in painting-you'll complete my downfall. (Financier 144)

Since Dreiser does not address any specifics in regards to the nature of this "downfall" and "ruin", one might argue that Cowperwood actually talks about a financial disaster due to his spending large sums of money in collecting art. However, nowhere throughout "The Trilogy" does any evidence point to that assumption. Not the acquisition of art, but a natural disaster, the fire of Chicago, eventually triggers Cowperwood's first financial bankruptcy. In fact investing in paintings is described as a possible way of accumulating money, "He tells me the great pictures are going to increase in value, and what I could get for a few hundred thousand dollar now, will be worth millions later" (Financier 144). Cowperwood's line that "art will be my ruin" rather points toward the relationship between himself and art and what art might or will do to him. It might lead to his estrangement from that part of his character that desires more wealth and 
fame and whose goal is not directed toward spiritual growth. Though some critics interpret Cowperwood's acquisition of art as merely another way of expressing power and his will to posses, he never actually attempts to use art as an investment. Even after losing money at the dissolution of his art collection ( a result of the Chicago fire and the subsequent crash at the Philadelphia stock exchange), “... some of his pictures, for lack of appreciative understanding, were disposed of at much too low a figure" (Financier 405). His desire for art has not been blemished by the financial loss and he is later depicted as, “. . a appreciating almost every suggestion of a delightful picture in nature" (The Titan 11). Art as Cowperwood's ruin must, as McAleer correctly states, point to a way to overcome his materiality, his search for fulfillment in fame and wealth. On the other hand it is questionable whether Dreiser really intended simply to refute materialism in favor of art. Why then did the author devote so much attention to creating his financier-artist, if not in an effort to place art above finance?

Cowperwood cannot be grappled with as merely a self-seeking materialist, driven by an insatiable desire to possess more and more objects of art. It is true that in the beginning of his life, one of his main goals was material possessions, but this goal evolves into his obsession with art and women, "Wealth in the beginning, had seemed the only goal, to which had been added the beauty of women. And now art, for art's sake-the first radiance of rosy dawn-had begun to shine in upon him, ..." (Financier 145). The great importance of his collection of art becomes apparent if we take a closer look at what this collection consists of and how the protagonist evaluates its significance.

Cowperwood's art collection becomes one of ". . the most important in the West-perhaps in the nation, public collections excluded. He began to envision himself as a national figure, possibly even an international one" (Stoic 346). 
All in all Cowperwood collects more than 300 pictures among them famous works by painters such as Rembrandt, Holbein, Frans Hals, Reynolds, Van Dyck, Ruysdal, Hobbema, Teniers and Turner. An art collection of these dimensions evidently must reflect more than Cowperwood's aptitude for lucrative investments. It rather shows his strong connection with great art as an attempt to lash himself aesthetically to a place that rescues him from the material aspects of life. When he comes into contact with art, the language is similar to the description we find when he talks of his passion for women " . . a strange uncertain feeling of real affection [creeps] over him. The man's great love was for art. It was hypnotic to him" (Titan 195).

In the "Trilogy's" last book the death-stricken Cowperwood talks of the significant role his art museum in New York has played in his effort to grapple with life:

... 'In fact Aileen, I don't know if you ever realized how much that place has meant to me. It has helped me to live through the endless practical problems to which I have had to devote myself. In building it and buying things for it, I have tried to bring into my life and yours the beauty which is entirely outside of cities and business.' and as Cowperwood talked on, Aileen at last realized to a degree, at least, and perhaps for the first time, what all this meant to him, and again she promised to do everything as he directed. (Stoic 274)

This passage gives Cowperwood's art collection an almost sacred touch. The museum-like mansion he has built to accommodate his paintings has brought him the peace needed to cope with society and the business world, like some people find comfort in their belief and religion. As a young man, Cowperwood's life motto could have been condensed into three words "I satisfy myself"; he transcends his self-satisfying premise toward the end of his life and 
for the first time displays concern for the public. His will stipulates that the mansion and the art collection be open to the public as a museum.

Why does Dreiser attempt to redefine the term artist and financier in the character of Cowperwood? I see it as Dreiser's attempt to reconcile the material aspects of finance with the spiritual qualities of art, though ironically Cowperwood's many affiliations with art end in a dead end road, represented by the mausoleum-like Fifth Avenue mansion and the tomb. But Dreiser seems to have the urge for solutions and closure, so we might look to the final chapters of The Stoic for an explanation. In India Berenice learns that the ". . face of Brahman reflected through all forms and designs. We think we worship beauty, but we are really worshipping the face of Brahman shining through. The Reality behind the scenes" (Stoic 319). The face of Brahman or God shining through any kind of beauty supports an understanding of Cowperwood's desire for art as a spiritual search for the divine. The search motif has been discussed in the first chapter of this work on the role of women in the "Trilogy of Desire". Evidently art constitutes another strategy to resolve the conflict between the material and the spiritual. Berenice's final view emphasizes his "... constant search for beauty in every form" (Stoic 305), and the financier in fact prefers art to reality. At the beginning of The Financier Cowperwood realizes that he could best admire nature through some interpreter, namely through the eyes of an artist. At that time he is unclear about the reason he needs the artist to admire nature. Cowperwood's interest is directed in finding "the reality behind the scenes", he needs to use art to transcend material reality. Art, his artistic way of handling millions of dollars, creating railroad lines and finally underground lines in London, all these threads in Dreiser's "Trilogy" are woven into the protagonist's spiritual quest and his attempt to see through the illusions of material reality. 
With the help of art and the interpretation of nature through the artists, either by Cowperwood himself or through the artists of his collection, he attempts to find a way to create a connection between the material and the spiritual world without elevating one above the other. 


\section{Chapter Four}

\section{Women}

This chapter discusses the role of women in The Financier, The Titan and The Stoic. Opposed to the previous chapters on finance and art, we are now looking at Cowperwood on the level of human relationships adding another layer of complexity to resolve the age-old division between the material and the spirit.

When Frank Cowperwood first shows interest in women, he displays a tendency to manipulate these young women into friendship with him, by buying them candy for instance. He is described as standing somewhat above or outside traditional morality. Early on in his life he realizes that "... There was great talk concerning morality, much praise of virtue and decency, and much lifting of hands in righteous horror at people who broke or were even rumored to have broken the Seventh commandment. He did not take this talk seriously" (Financier 37). Cowperwood's way of seeing and understanding women is ". . temperamental rather than intellectual" (Financier 37) This might explain his rejection of conventions such as virtue and decency. However it would be rash to conclude that Cowperwood's attraction to women can be explained solely on the basis of temperament and passion. The women he sees on the street, the prostitutes in the whore houses, at first astonish him, but he soon comprehends the nature of the " . . false tinselglitter of the house of ill-repute ..." (Financier 37). He feels disgusted by "the 
fact that they [women] could, with a show of affection or good-nature, receive man after man ..." (Financier 37). Prostitution appalls Cowperwood, not from a moral point of view, but because he seeks something more " . . subtle, individual, personal" (Financier 38). Women reflect his urge to live "... richly, joyously, fully--his whole nature craved that" (Financier 57).

The abstract nature of Cowperwood's desire to live richly and joyously might be an indication that women will constitute more in Cowperwood's future than physical attraction and sexual satisfaction. The young Cowperwood however is apparently driven by a great passion for his first love ". . . he wanted her in an urgent passionate way. He could not think of her reasonably,..." (Financier 45). Lillian Semple strongly attracts with her beauty and a mental and physical "lure" that leaves Cowperwood unable to resist. Though Lillian is older than Cowperwood and married when he meets her, he perseveres in his courtship of Lillian and after years of platonic friendship Lillian's husband dies unexpectedly. Subsequently Cowperwood's passion resurfaces and though, Lillian is hesitant at first, because of their difference in age , Cowperwood forcefully talks her into marrying him. The marriage not only satisfies Cowperwood's passion but it also gives his life meaning: "There was a good deal to his home idea, after all. That was the way life was organized, and properly so-its cornerstone was the home" (Financier 59). For the first and only time, he adapts to the role of a traditional family father and husband, enjoys the amenities of the shelter and peace of family-life. For a period of more than four years, the family satisfies Cowperwood's hunger for life, his desire for beauty and "... the idea of self-duplication ${ }^{1}$..."(Financier 59).

\footnotetext{
1 he wants to have chidren with his wife
} 
However, from the start there are differences in thinking between the married couple. When Cowperwood and Lillian get married they decide to move into the house she has inherited from her deceased husband. Cowperwood, objecting to the style and artistic taste of the interior and the furniture redecorates their new home with objects of art reflecting his taste but not Lillian's: "Mrs. Cowperwood was shocked by the nudity of the Venus which conveyed an atmosphere of European freedom not common to America; but she said nothing" (Financier 56). Their attitudes toward marriage are similarly incompatible. Lillian views her second marriage like her first, leaving no space for growth and therefore for life or change itself. She prefers to view marriage as something static, an institution, a matter of fact arrangement that would not allow each partner to learn and grow and eventually live richly as Cowperwood desires. Marriage to her is understood as a “. . . solemn fact which contained no possibility of mental alteration" (Financier 60). Cowperwood on the other hand is "bustling about in a world which, financially at least, seemed all alteration-there were so many sudden and almost unheard-of changes" (Financier 60).

Lillian's inability to accept the need to grow intellectually and mentally evolves into an alienation, and eventually triggers Cowperwood's interest in other women. The vibrant Aileen Butler, daughter of a wealthy Irish businessman who made a fortune in garbage contracts with the city of Philadelphia, contrasts with Lillian, whose, " ... health was really not as good as it had been-the care of the two children and a late undiagnosed tendency toward gastritis having reduced her. In short she was a little run down nervously and suffered from fits of depression" (Financier 73). Aileen reflects vi- 
tality; she is a 'bright bird radiating health and enthusiasm-a reminder of youth in general" (Financier 73).

These women can be seen as representing various evolutionary stages in the life of the protagonist. Lillian appealed to Cowperwood's early passion and desire for children, the happiness that he hoped to find in family. She is the only woman with whom he has a child. Yet her qualities as a mother, her income, the stable, almost static element grounded in moral family life all conflict with his quest for vitality. His wife Lillian embodies the most conventional form of relationship, a relationship concerned with down to earth issues such as rearing children, maintaining conservative morality in following traditional roles in family life.

With the introduction of Aileen, Cowperwood's total break with conventional morals is begun. He now questions morality even more than before to justify a desire that unavoidably would lead to breaking the seventh commandment. He is very well aware that this conduct might lead to complications in his effort to be a respected member of society and fulfill his dream of wealth and fame, therefore his plan at first is to keep his extramarital relationships secret to avoid problems with his wife and Philadelphia society.

Apart from Aileen's beauty, health, vitality and enthusiasm, Cowperwood feels strongly attracted to her rather unconventional personality. Aileen, daughter of wealthy Irish Catholic parents, finds herself only marginally concerned with Catholic morals and the church's attempt to lead its members onto the "right" path:

... The confessional, dim on Friday and Saturday evenings, when the church was lighted by but a few lamps, and the priest's warnings, penances, and ecclesiastical forgiveness whispered 
through the narrow lattice, moved her as something subtly pleasing. She was not afraid of her sins. Hell, so definitely set forth, did not frighten her. Really it had not laid hold on her conscience. (Financier 79)

Like Cowperwood, she transcends conventional moral views and refuses to accept the Catholic belief in a punishing God, the idea of Hell and the categorization of human behavior into good deeds and sins.

Quite contrary to Lillian, Aileen has an almost feigned interest in "... music and the idea of painting, though she had no talent in that direction; and books, novels, interested her, but she could not get them" (Financier 80). Cowperwood feels attracted to the potential of Aileen's affiliation with art, since Lillian does not share his aspirations to the arts. However, as we can already sense from the way Aileen's "interest" is qualified in the aforementioned passage, she is just connected with art superficially, so will never truly be able to share Cowperwood's fascination with art. The advantages of wealth have a grip on Aileen, yet she realizes that life bears more than these material values. As opposed to the static Lillian who is firmly grounded in material reality, Aileen has a more conflicted character, one that shows an aspiration beyond the material world, yet is not quite on a spiritual quest like the Berenice we meet later. Aileen likes too much to surround herself with beautiful jewelry, shoes, stockings, lingerie, laces, perfume and cosmetics. The Butler's family home is a constant eyesore to her, because it lacks representational value and grandeur. Lillian, who is able to see Aileen from another point of view talks of her as "the little snip", who "... thinks the sun rises and sets in her father's pocket" (Financier 81), and whose interest in art and music is merely "pretended" (Financier 81). As we learn later in The Titan and finally in The Stoic, Aileen's interests and ambitions never truly go be- 
yond a refined sense of clothing and her fruitless and vain efforts to be accepted in society. If we see Aileen as an extension of Cowperwood's personality it is not surprising that his relationship with her will never be dissolved like his marriage with Lillian. Cowperwood has clearly evolved from the person he was when marrying his first wife. The divorce from Lillian shows his moving one step ahead in an evolutionary process. The marriage endures because Cowperwood and Aileen deal with similar unresolvable conflicts. He never fully leaves the conflicted character of his wife, who is so much connected to the material side of life and shows so few spiritual qualities especially when compared with Berenice. Cowperwood appreciates Aileen's enduring love; more than once it sends him into raptures. It is a spiritual quality; she is so absolutely committed to her beloved husband that she turns into a martyr. Her love and sacrifice, which is essentially anti-self, elevates Cowperwood to a God-like figure, a quality he gains through Aileen's love. This dynamic allows their relationship to endure throughout all three of the novels in the "Trilogy". Aileen creates "... in him [Cowperwood] a sense of the distinguished and a need for it which had never existed in him before to the same degree" (Financier 145). Her love transcends the boundaries of human love and is elevated to divine love. She, the nonseeker, holding that largeness of spirit, gives and sacrifices herself for Cowperwood.

... The temperament of man, either male or female, cannot help falling down before and worshipping this non-seeking, sacrificial note. It approaches vast distinction in life. It appears to be related to that last word in art, that largeness of spirit which is the first characteristic of the great picture, the great building, the great sculpture, the great decoration-namely, a giving, freely and 
without stint, itself, of beauty. Hence the significance of this particular mood in Aileen. (Financier 154)

Cowperwood and Aileen finally get married after a long struggle with Lillian to agree to divorce. By this time Aileen has been Cowperwood's mistress for a number of years and the novelty of Aileen has already worn off; Cowperwood's desire for new life is again rising.

... Although he had only so recently acquired Aileen legally, yet she was years old to him as a mistress, and the first engrossing-it had been almost all-engrossing enthusiasm was over .... So it was and so ye was. He did not want to hurt Aileen's feelings by letting her know that his impulses thus wantonly strayed to others, but so it was. (Titan 104)

Nonetheless the failure of the marriage results not only from his insatiable desire for life but also from the unresolved conflict and struggle between the apparent artistic and therefore the more spiritual aspects of Aileen and her predominant material desires and aspirations--between her sacrificial love and her aspiration to wealth and luxury. Even her liberal, rebellious viewpoint toward the church, morals and society stands in contrast with her desire to become Cowperwood's legal wife and her unceasing efforts to be accepted by society. Aileen never finds a solution or middle way to these inherent contradictions. In fact, her fate seems to be in more suffering, as expressed in her alcoholism and bitter and cynical attitude toward love. Aileen as a reflection of the protagonist gives us insight into the conflicts Cowperwood faces, but fails to resolve. The character of Aileen can be seen as a strategy to look at certain elements of Cowperwood's character from a different viewpoint. 
Aileen gradually loses what Cowperwood so admired in her, the vitality and radiance of life; her only source of self-confidence, namely society, has been reduced to almost nothing. She seems unable to compensate for this and gradually loses her once so attractive character. Cowperwood senses her distress and tries to direct her toward the "... plenty of things to live for in this world besides society" (Titan 100). Even though these "other things to live for" are not explicitly mentioned, I suspect that he is voicing his desire to look for fulfillment not merely on a societal level, but also in the world beyond the material. Aileen's aspirations for art, painting, music, which might have had the potential of such a spiritual quest, never really grow into anything substantial. Cowperwood realizes the discrepancy between his aspirations and those of his wife.

In connection with Aileen, Dreiser raises several questions in authorial comments on moral and marriage. Dreiser states, "It is a curious fact that by some subtlety of logic in the Christian world, it has come to be believed that there can be no love outside the conventional process of courtship and marriage" (Financier 131). He goes on to back his statement with historical data of pagan belief,

... Pagan thought held no such belief. A writing of divorce for trivial causes was the theory of the elders; and in the primeval world nature apparently holds no scheme for the unity of two beyond the temporary care of the young. . . Life cannot be put into any mold, and the attempt might as well be abandoned at once. . . Like is drawn to like. Changes in temperament bring changes in relationship. Dogma may bind some minds; fear, others. But there are always those in whom the chemistry and physics of life are large, and in whom neither dogma nor fear is operative. (Financier 131)

The narrator critiques conventional Christian morality, specifically in regard to marriage and divorce as restricting the chemistry and physics of life, argu- 
ing that humans go through various changes, hence a static rule, or "the mold" into which the church tries to fit life is limiting and unfit to allow change. A discussion of Christian morals might seem outdated today, however it contributes to a better understanding of Dreiser's underlying point, which emphasizes an acceptance of life forces that are beyond human control. And this would indicate Dreiser's acknowledgment of something (he does not specifically name it) outside the human world, namely the spiritual realm. In other words, even though Dreiser uses naturalistic language such as "the chemistry and physics of life", he should not be misunderstood as being limited to this world view, it rather indicates his desire for answers to the human condition in the world. In Dreiser's view the protagonist Cowperwood does not act immorally by his failure to keep the marital commitment to either to his first wife Lillian or his second wife Aileen; on the contrary, Cowperwood is characterized as one of those people in whom "neither dogma nor fear is operative" (Financier 131). For the narrator people are attracted to each other according to changes in temperament which bring changes in relationships, regardless of commitment, holy sacrament or family duties. Hence, strict Christian morals hinder the true seeker of love, and morals should therefore be abolished. Cowperwood's break with conventions places him in a position to see life from a different point of view, a strategy to approach the conflict between material and spiritual outside of society, a society too static, not yet ready to leave enough ground for new ideas.

Aileen "... [is] drawn [to Cowperwood] as planets are drawn to their sun" (Financier 125), but the sun and the planet soon drift in different directions. Apart from Aileen's sacrificial love for her husband, she lacks impor- 
tant character traits that Cowperwood craves. Cowperwood and Aileen move to Chicago to start new business ventures after his reputation in Philadelphia has been severely damaged due to the financier's financial scandal and resulting imprisonment. His wife, Aileen seems to be unable to become established in their new hometown, Chicago, and utters the hope that her husband's money would help the couple to become accepted in Chicago society, "Oh, if only Frank's money could buy them position and friendship in this interesting world; if it only would! She did not quite realize how much on her own personality, or the lack of it, this struggle depended" (Titan 65). This lack of character and her increasing tendency to rely on material means to compensate for her deficiency, prompts Cowperwood's alienation process from Aileen.

Large portions of The Titan are devoted to Cowperwood's quest for life in numerous more or less serious love-affairs that he initiates with women such as Ella F. Hubby, Josephine Ledwell and Rita Sohlberg. Rita, wife of a rather unsuccessful Danish musician, plays a more important role in Cowperwood's life than most of his other affairs.

Rita Sohlberg is one of the many women who prepares Cowperwood for his final relationship with Berenice Fleming, which I will discuss in more detail later. In the relationship with a woman like Rita Sohlberg, Cowperwood grows intellectually and spiritually in a way his wife could not encourage or have empathy with. For instance, Aileen does not share Cowperwood's growing interest and compassion for art and music. With Rita Cowperwood finds comfort, even counsel and advice in regard to developing a more defined taste in matters of art. Like most of these relationships, however, the liaison with Rita Sohlberg is not lasting: 
... Cowperwood was trained by Rita into a really finer point of view. He came to know better music, books, even the facts. She encouraged him in his idea of a representative collection of the old masters, and begged him to be cautious in his in his selection of moderns. He felt himself to be delightfully situated indeed. (Titan 121)

Though Cowperwood realizes that she represented a type of woman he was beginning to feel very attracted to, ". . . his temperament ached for he must have something like that. Truth to say, he must always have youth, the illusion of beauty, vanity in womanhood, the novelty of a new untested temperament, ... " (Titan 186). Rita reflects Cowperwood's strong desire for art and above all eternal life. Art and beauty with their timeless qualities illustrate eternity; Cowperwood's need for eternal youth can be met only by relating to new young women.

His quest for new temperaments, beauty and youth leads to more brief intimate relationships. Stephanie Platow for example teaches Cowperwood a lesson about his role as heart-breaker. She is the only woman in his life who reportedly hurts him, after he discovers Stephanie's dishonesty about another man in her life, he "... knew for once what it was to love and lose-to want ardently in his way and not to have-now or ever after" (Titan 221). For the first time the protagonist contemplates the "... terrible things passion and love are-how they make fools of us all" (Titan 288), since he becomes for once the victim and sufferer of an unfulfilled passionate love.

After these rather dissatisfying relationships, Cowperwood finally wonders if there is a right woman for him and if there were, whether he has found her yet. Cowperwood begins to realize that his desire for beauty, youth and hence eternity might not be found in any woman. So far his 
relationships with women have been characterized mainly by passion and emotion. Passionate love, Cowperwood senses, does not resolve any of his conflicts. However, as I have pointed out earlier, women represent evolutionary stages in the life of the protagonist, illuminating the various issues and elements of Cowperwood's character. We can see the financier's subtle changes as he gains insight in the relationships he has experienced. The kind of woman he desires toward the second half of the Trilogy now must have, apart from youth, an ability and sensitivity for the world beyond mere material. Cowperwood becomes more introspective, a characteristic illustrated by the feelings of compassion for his suffering wife Aileen, . . a a kind of sorrow over the inevitable consequences of his own ungovernable disposition, the will to freedom within himself. Change! Change! the inevitable passion of things" (Titan 292). Cowperwood is depicted as being governed by outward forces, his urges desires and passion (the ungovernable disposition) on a quest to free himself from his worst enemy, his conflicting desires. But social constraints and obligations keep him tied to the marriage with Aileen and hence to the person that is so much connected to the material aspects of life. Cowperwood wants change, though his wives, depicting these characteristics of his, counterbalance and hinder change with their unwillingness to change.

In despair, disillusioned, aimless, purposeless, unable to perform the leap, Cowperwood seeks consolation in church and a so-called "superior morality", "On Sunday, when he went to church with his wife, he felt that religion was essential and purifying. ... God was God, morality was superior, the church was important. It was wrong to yield to one's impulses, as he found it so fascinating to do" (Titan 297). This passage indicates 
Cowperwood's failure to find a meaningful purpose and direction in life with his many affairs and liaisons.

To his rescue comes Berenice Fleming. Still a child when he first meets her, she initiates Cowperwood's contemplation on his aging, "Cowperwood for the first time in his life felt himself getting old. In spite of the vigor of his mind and body, he realized constantly that he was over fiftytwo, while she was only seventeen" (Titan 328). In this light he acknowledges the relative triviality of his deeds and efforts in the light of his certain path to death. Again we find confirmation in the strategy that has been used so far: it is only in the relationship with a woman in which he raises profound questions about the human condition. Finally the protagonist has found an equal partner, a soul-mate who "could and would command the utmost reaches of his soul in every direction" (Titan 359). Berenice, though she could be his daughter, seems to be compatible with Cowperwood in many respects, 'Here he was, long, crowded years of conflict and experience behind him, and yet this twenty-year-old girl, with her incisive mind and keen tastes, was apparently as wise in matters of general import as himself" (Titan 359). In fact Berenice takes the leading role when she asks Cowperwood, "' Do you think the senses of the world are only five?'" (Titan 359). This young woman alludes to Cowperwood's restricted understanding of the world, limited to sensory perception, whereas she seems capable of the sixth sense, which is often associated with spiritual vision or intuition. Berenice Fleming is without doubt the most influential female character in Frank Cowperwood's life. She directs and redirects his life and acts as his spiritual and mental counselor for the profound questions that have tormented Cowperwood's mind ever since he began to seek answers to his questions of the organization of life and its 
purpose. Berenice senses his perpetual quest in finding his ideal in a living woman, ". . . 'we do have a polestar, but you do not seem able to find it. Do you expect to find your ideal in any living woman?'” (Titan 423).

Cowperwood seems to have found his ideal in Berenice; for him she represents a level of love that he has never experienced, "At last he saw clearly, as within a chalice like nimbus, that the ultimate end of fame, power, vigor was beauty, and that beauty was a compound of the taste, the emotion, the innate culture, passion, and dreams of a woman like Berenice Fleming" (Titan 427).

Whereas the protagonist seems to be like "... some big engine or machine that's tearing full speed somewhere, but doesn't know exactly where" (Stoic 12), Berenice not only gives Cowperwood a new view on life, but she has the potential to change the values that used to be most influential and dominant in his life up to this point. The material possessions, his immense holdings (he was by then one of the wealthiest men in the United States) lose their importance in the light of his " . . one great dream of his life really come true. What of defeat? There was no defeat! It was love that made life, certainly not wealth alone." These new thoughts indicate a possible shift from the material value of riches and worldly possessions to the spiritual value of love. Berenice's great influence and also positively destructive power is epitomized in the following snow-man scene:

... And I made you so real. He was so big and cold, and needed me so much out here. And now I'll have to destroy him, my poor snow-man, so that no one will have ever truly known him but me.' And all of a sudden she dashed the figure apart with Cowperwood's cane. 'See I made you, and now I am unmaking you!' And as she talked she powdered the snow through her gloved fingers, while he gazed at her wonderingly. (Stoic 63) 
In this passage Berenice alludes to Cowperwood's need for spirituality, instead of his mighty endeavor to transcend the material world by his paradoxical effort to add ever more possessions and expand his worldly power. In a violent blow, she destroys Cowperwood's big and cold material image in the form of the snowman. The implication here is that in order for Cowperwood to leave his old beliefs and values, this part of his personality must be destroyed to move on to the spiritual realm. Only with this extreme and violent act of destruction of the former possession-driven Cowperwood will Berenice be able to truly know him and hence Cowperwood to know himselfthis unexplored part of his character.

Berenice Fleming not only mentally leads the protagonist into new lands and regions he had never before seen or imagined, but this travel also manifests physically in their journeys to England and Norway. Instead of visiting the most commons sites in England, Berenice directs their tour almost exclusively to the cathedrals, foreshadowing the vision she has of her life in the future, "Now ... here ... in this place ... perfumed with memories and moonlight ... something that whispered of quiet and peace ... solitude ... fulfillment ... a desire to create something utterly beautiful, so that her life would be complete and significant" (Stoic 147). This excursion to sacred places also contrasts with Aileen and Tollifer's simultaneous excursion in Paris. Rather than seeing sacred places they decide to visit the Paris cafes, smart shops, and popular resorts again illustrating Aileen's strong connection with and interest in the material side of life.

The voyage to Norway is marked by Cowperwood's amazement by this strange land, characterized as being entirely free of industrialism. Norway 
constitutes the antithesis of industrial America, a hectic society where money rules. In this Scandinavian oasis, Cowperwood finds peace and comfort in the simplicity of Norwegian people: "he felt that these people had more from life in sheer beauty, simple comfort, and charming social customs than he and thousands of others like him who were so strenuously engaged in accumulating money" (Stoic 249). The spiritual journey Berenice leads Cowperwood on is reflected in their physical travel to England and Norway. The experience of the peaceful Norwegian life-style, their simplicity yet not naiveté, could have resulted in a new model for his future, but instead he uses his renewed energy only to proceed further to accumulate money despite having resented this only a few days earlier in Norway.

Shortly before his death, Cowperwood, by now seriously sick and resting in a New York Hotel with Berenice secretly residing in the same place, develops feelings of remorse about Aileen's enduring love, especially in memory of her support during his imprisonment in Philadelphia (though at the same time lying to her about the whereabouts of Berenice, who visits him frequently). Triggered by a story about the love of a young girl for the spiritually brilliant monk, and the savage brutality of her father, Cowperwood remembers the love of bygone days that he and Aileen once shared. Ironically he decides to honor their love by burying it in a tomb, a place of death which he wants to be built for both of them.

Cowperwood appears to foresee his death that follows shortly after his vacation to Europe. On board the ship, where he eventually dies, he talks to Berenice about the immortal nature of their love, "' This love of ours is not just for today, it is forever. It will live in you wherever you are, and yours in me. We shall not forget. Darling rest and be happy'“ (Stoic 282). 
Cowperwood's insistence that their love is "forever", shows his growing urge for the eternity he desperately seeks.

The novel could have ended with Cowperwood's death, leaving us in ambiguity about the fulfillment of the protagonist's desires, but the end of The Stoic delivers another unexpected solution. Shifting the focus, which has been solely on Cowperwood, another world, namely India seems to be Dreiser's solution for Cowperwood's conflicts. Berenice's travel to India which I will discuss in the concluding chapter gives answer to a question Dreiser has not asked in his "Trilogy". The shift from Cowperwood to Berenice as a strategy to see Berenice as Cowperwood's extension leads us into a place, a space that is not part of the world Cowperwood has moved about. A solution such as this points toward the insoluble nature of the division between the material and the spirit. 


\section{Chapter Five}

\section{Conclusion}

In the preceding chapters I have discussed three of the main themes, finance, art and women in Dreiser's "Trilogy". All these themes can be seen as strategies to resolve the age-old division between the material and the spiritual, a division that is being reflected in the partition on Dreiser criticism that I have discussed in the first chapter.

Dreiser attempts to redefine the term finance, a subject matter that is most closely related to the material world. He tries to convey the notion that finance is an art, to make acceptable that Cowperwood, though largely motivated by his desire for power, can also be seen as pursuing finance as a mode of aesthetic appreciation. If Dreiser is successful in conveying this redefinition of finance, we should then see a connection to the other two themes; Cowperwood's responsiveness to feminine beauty and his connection to art. If we look at Cowperwood however, we meet a financier whose main goals are wealth and power in the acquisition of money. The power this money would give him answers his deepest call, "I satisfy myself". The first time Cowperwood questions his goal is in the Philadelphia penitentiary where his" ... own life seemed very trivial in view of these, and he found himself asking whether it was really of any significance or importance" (Financier 436). The protagonist's doubts and questions reappear throughout the "Trilogy", revealing his urge to move onto higher levels of 
consciousness. In The Titan Cowperwood realizes that the pursuit of money has kept him from gaining knowledge in other fields, such as astrology, literature etc., but his losses in other fields and the thoughts about the triviality of his goals fail to change the horizontal movement of his life. His iron will, a highly efficient instrument that contributes to his outstanding financial success, also becomes his greatest obstacle in the urge to look beyond mere materialism. Even in the last novel, The Stoic, Cowperwood gains great excitement from his work and the financial power that accompanies it.

Though Cowperwood's desire for wealth and fame never falters, the fictional emphasis on finance changes significantly within the "Trilogy". The detailed descriptions of the financial world that occupy much of The Financier give way to philanthropic and spiritual issues in The Titan. With the introduction of Berenice Fleming, Cowperwood again realizes with "great force, how comparatively unimportant in the great drift of life were his own affairs when about him was operative all this splendid will to existence, as sensed by her" (Titan 358). This realization and Cowperwood's subsequent contradictory actions (he goes into one of the most ambitious struggles to obtain a majority hold on the London underground) magnify his struggle between the material and the spiritual world. A struggle which remains unresolved is Cowperwood's connection with the strategy of finance as art; it fails insofar as it contradicts Cowperwood's actions and his real goals which are comprised in wealth, fame and power. The protagonist's change (if there is any change at all) is not congruent with the fictional change. But the strategy succeeds in establishing a credible character who stands on a different level than society. With the creation of this extraordinary position Cowperwood is able to look at society from a different point of view. It 
enables the narrator and Cowperwood to look for answers in a more free and creative environment than from the position as part of society. This strategy is used throughout the "Trilogy" in all of the previously discussed themes.

Apart from the redefinition of finance, the term "artist" is given new meaning. Not only does Cowperwood show an early interest in art, but more importantly the financier himself is depicted as an artist. The tools of his creations are the railroad lines of Chicago, the architecture of the buildings, the Fifth Avenue mansion in New York etc.. Even though Cowperwood's artistic talents have been conveyed convincingly (numerous characters see the artistic talent in him), his creativity and aesthetic sense are not the sole core of his projects and financial ventures; for he is also motivated by his desire to display power and his superiority to and outside of society.

For Cowperwood art is his connection with nature, a possible path that might lead to his estrangement from that part of his character that desires more wealth and fame and whose goal is not directed toward spiritual growth. He would like to use art as a vehicle to transcend the material world since, ". . it is the spirit of art that occupied the center of Cowperwood's iron personality,... (Titan 399). In the acquisition of art, he can see the world through the eyes of an interpreter namely the artist trying to perceive beyond apparent reality.

Cowperwood's art collection is finally housed in the grandiose Fifth Avenue mansion, a building that is mainly erected as a museum for art, more like a mausoleum than an actual place to celebrate art as life. Toward the end of the "Trilogy", art becomes increasingly associated with images of death. The tomb he erects to commemorate the past love between Aileen and him expresses his desire for self-presentation and the quest for immortality in 
art. The love he buries in the tomb parallels his art collection that rests in the mausoleum-like Fifth Avenue mansion. As with finance, art represents a strategy in an attempt to reconcile the material with the spiritual. It reflects another facet of Cowperwood's character though this strategy again fails to resolve the protagonist's conflicting elements.

The last chapter on women discusses yet another attempt to reconcile the division and subsequent conflict between the matter and the spirit, from the more complex viewpoint of human relations. The women in Cowperwood's life can be seen as representing various levels in an hierarchical structured order. To his first wife, Lillian Semple, he is attracted with a great passion for her beauty and maturity. She reflects Cowperwood's traditional character which seeks happiness and fulfillment inside the rules and morals of society. For a number of years family life seems the answer and key to the mystery of life, but some of Cowperwood's desires appear impossible to satisfy in any relationship. Women reflect his urge for life, youth, and beauty. All of these aspects being only temporary phases in any person, he soon feels the desire to find these elements in a younger more lively woman. Aileen Butler has vitality; she is depicted as: "a bright bird radiating health and enthusiasm-a reminder of youth in general", though she, like any mortal person, eventually loses her health and youth in the course of the "Trilogy" (Financier 73). Aileen Butler, who becomes Cowperwood's second and last wife, represents her husband's conflicting elements of character most clearly. Though she aspires for more than mere materialism in life, another part of her strongly connects to the material side of life. 
Cowperwood's divorce from Lillian, his unconventional viewpoint on moral issues concerning marriage etc., again put the protagonist into a position outside society. This is a consistently used strategy that we also find in connection with finance and art to enable the protagonist to find new solutions to the conflict between material and spirit. From this stand marriage and conventional morals are seen as restricting the "chemistry and physics of life" and hence hindering the true seeker of love.

With the help of Berenice Fleming, Cowperwood realizes the futility of looking for an ideal in a living woman. He acknowledges the inherent contradiction in his search for immortality and eternity, for they can never be fulfilled in any living being. Berenice reflects Cowperwood's urge to connect to and learn about the world beyond materialism. He desperately wants to free himself from his wife, Aileen, though this task remains impossible as long as he has not reconciled and liberated himself from the issues that connect Aileen and him. (They share a strong connection to the luxury of the material world, wealth, societal recognition and sensual pleasures.) With the death of Cowperwood all three themes that Dreiser has used as strategy fail to resolve the protagonist's conflict between the material and the spiritual. He never fully commits to Berenice. Her role remains at the level of mistress and as a secret to his wife. Cowperwood commemorates his and Aileen's love that they once shared in a place of death.

The last chapters of the "Trilogy" reflect Dreiser's attempt to find closure and resolution to the questions he raised. Berenice's travel to India and her experiences with the spiritual wisdom of the guru might satisfy our romantic desire for resolution, but we should be aware that this ending, with Berenice acting out Cowperwood's failure in resolving his conflicting forces 
of the material and the spiritual, gives an answer to a question that has never been raised in the "Trilogy." It is fictionally incoherent with the preceding parts of the novel and tries to resolve in a quick-fix approach what Dreiser failed to reconcile in the detailed story of the life of Cowperwood. 


\section{Works Cited}

Primary Sources:

Dreiser, Theodore. The Financier. New American Library, Inc. New York, 1967.

- - The Titan. Meridian Classic. Ontario, 1984.

- - -. The Stoic. New American Library, Inc. New York, 1981.

Secondary Sources:

Asselineau, Roger. "Theodore Dreiser's Transcendentalism." Critical Essays on Theodore Dreiser. Ed. Donald Pizer. Boston: G.K. Hall, 1981. 92-103.

Elias, Robert H. Theodore Dreiser: Apostle of Nature. Emended ed. Ithaca, N.Y.: Cornell University Press, 1970.

Hochmann, Barbara. "Dreiser's Last Work: The Bulwark and The StoicConversion Or Continuity?"The Dreiser Newsletter. 14.2 (1983) : 1-15.

Lang, Peter. "Dreiser's Perpetual quest for the 'Reality of Life'." Rev. of The Quest for the Reality of Life : Dreiser's Spiritual and Esthetical Pilgrimage, by Miyoko Takeda. Dreiser Studies. 23.1 (1992) : 42-43.

Lehan, Richard. Theodore Dreiser. His World And His Novels. Southern Illinois University Press, Carbondale \& Edwardsville, 1969.

Lingeman, Richard. "Mencken, Dreiser And God." Menckenia, A Quarterly Review. 4 (1991) : $1-9$.

Pizer, Donald. The Novels of Theodore Dreiser: A Critical Study. Minneapolis: University of Minnesota Press, 1976.

... Critical Essays on Theodore Dreiser. G.K. Hall \& Co., Boston, 1981. 
Sherman, Stuart P. "The Naturalism of Mr. Dreiser." Critical Essays on Theodore Dreiser. Ed. Donald Pizer. Boston: G.K. Hall, 1981. 4-12.

Takeda, Miyoko. "The Theme Of Hinduism In The Stoic." Dreiser Studies. 20.2 (1989) : 28-33.

Vivas, Eliseo. "Dreiser, an Inconsistent Mechanist." Critical Essays on Theodore Dreiser. Ed. Donald Pizer. Boston: G.K. Hall, 1981. 30-37.

Zanine, J. Louis. Mechanism and Mysticism. The Influence of Science on the Thought and Work of Theodore Dreiser. University of Pennsylvania Press. Philadelphia, 1993. 